\title{
Comparison of the Gen-Probe Aptima HIV-1 and Abbott HIV-1 Qualitative Assays with the Roche Amplicor HIV-1 DNA Assay for Early Infant Diagnosis Using Dried Blood Spots
}

\author{
Julie A. E. Nelson ${ }^{1,2,{ }^{*}}$, J. Tyler Hawkins ${ }^{1,2}$, Maria Schanz ${ }^{1,2}$, Katie Mollan ${ }^{1}$, Melissa B. \\ Miller $^{3}$, John L. Schmitz ${ }^{1,3}$, and Susan A. Fiscus ${ }^{1,2,3}$ \\ ${ }^{1}$ UNC Center for AIDS Research, School of Medicine, University of North Carolina at Chapel Hill, \\ Chapel Hill, NC, USA \\ ${ }^{2}$ Department of Microbiology and Immunology, School of Medicine, University of North Carolina at \\ Chapel Hill, Chapel Hill, NC, USA \\ ${ }^{3}$ Department of Pathology and Laboratory Medicine, School of Medicine, University of North \\ Carolina at Chapel Hill, Chapel Hill, NC, USA
}

\begin{abstract}
Background-The current gold standard for infant diagnosis of HIV-1 is the Roche Amplicor Qualitative DNA assay, but it is being phased out.

Objective-Compare the Abbott qualitative assay and the Gen-Probe Aptima assay to the gold standard Roche DNA assay using dried blood spots (DBS).

Study design-The Gen-Probe Aptima and Abbott qualitative HIV-1 assays were compared to the Roche DNA assay for early infant diagnosis. Specificity and sensitivity were determined for the three assays using DBS from 50 HIV-exposed uninfected infants and 269 HIV-1 infected adults from North Carolina, respectively. All of the negative and 151 of the positive DBS had valid results on the 3 different assays, and an additional 118 positive DBS had valid results on the Roche DNA and Aptima assays.
\end{abstract}

Results-All three assays were very specific. The Roche DNA assay was the most sensitive (96.7\%) over a wide range of HIV PVL, including samples with PVL $<400$ copies $/ \mathrm{ml}$. Restricted to samples with PVL $>400$ copies/ml, the Gen-Probe Aptima assay had sensitivity (96.5\%)

\footnotetext{
(C) 2014 Elsevier B.V. All rights reserved.

"Corresponding author: Julie A. E. Nelson, Center for AIDS Research, CB\#7295, University of North Carolina at Chapel Hill, Chapel Hill, NC 27599-7295.

Publisher's Disclaimer: This is a PDF file of an unedited manuscript that has been accepted for publication. As a service to our customers we are providing this early version of the manuscript. The manuscript will undergo copyediting, typesetting, and review of the resulting proof before it is published in its final citable form. Please note that during the production process errors may be discovered which could affect the content, and all legal disclaimers that apply to the journal pertain.

Competing interests

Abbott Qualitative HIV-1 Assay kits were provided by Abbott Molecular. JAEN and SAF have served as advisory board members for Roche Diagnostics and Hologic Gen-Probe, and have served as speakers for Abbott Molecular.

Ethical approval

None required.
} 
comparable to the Roche DNA assay (98.8\%). The Abbott Qualitative assay was the least sensitive and only had sensitivity above 95\% among samples with PVL over 1000 copies $/ \mathrm{ml}$.

Conclusions-The Abbott HIV-1 Qualitative assay was not as sensitive as the comparator assays, so it would not be a useful replacement assay, especially for infants taking antiretroviral prophylaxis. The Gen-Probe Aptima assay is an adequate replacement option for infant diagnosis using DBS.

\section{Background}

Diagnosis of HIV infection in infants requires detecting components of the virus since exposed infants receive anti-HIV antibodies from their mothers. For many years the gold standard for HIV-1 diagnosis in children under 18 months of age was the Roche Amplicor HIV-1 Qualitative DNA assay, version 1.5 (Roche Diagnostics, Indianapolis IN; abbreviated Roche DNA)[1], a manual assay requiring just a thermocycler and an ELISA plate reader. However, this assay is being phased out (Roche announcement dated April 17, 2014), thus a replacement infant diagnosis assay is needed, especially one for use with dried blood spots (DBS). DBS do not require phlebotomy or cold-chain storage, are easy to collect and transport to central laboratories in resource-limited settings, and have been validated for both HIV PVL monitoring and infant diagnosis [2-24].

Abbott has developed a qualitative HIV-1 assay for their m2000 platform which detects both HIV-1 RNA and DNA. We previously compared the Roche DNA to the FDA-cleared GenProbe Aptima HIV-1 Qualitative assay (Hologic Gen-Probe, San Diego CA) [25], and included that platform in this comparison. WHO recommends that HIV-1 virological assays used for early infant diagnosis should have sensitivity of at least $95 \%$ and specificity of at least $98 \%$ [26]. We assessed the performance of each of the assays to those targets.

\section{Objective}

Compare the Abbott qualitative assay and the Gen-Probe Aptima assay to the gold standard Roche DNA assay, using DBS generated from patients from our local study population.

\section{Study design}

DBS were prepared from EDTA whole blood using 50 $\mu$ l spotted on Whatman 903 cards

(GE Healthcare Biosciences, Pittsburgh PA). To assess specificity, DBS were tested from 50 HIV-exposed uninfected infants from North Carolina who were screened previously for HIV infection (Roche DNA using pellets from $0.2 \mathrm{ml}$ whole blood). Sensitivity was assessed using DBS from HIV-1-infected adults from North Carolina who were tested for HIV plasma viral load (PVL), since perinatal HIV transmission in North Carolina is currently rare (S. Fiscus, unpublished observation). DBS from 274 HIV-1-infected adults were tested with the Roche DNA and Aptima assays, 152 of the 274 were also tested with Abbott Qual. Depending on the HIV RNA assay used at the time of collection of the HIV-positive DBS, the lower limit of quantitation was either 400 or $40 \mathrm{cp} / \mathrm{ml}$. Quantifiable PVL ranged from 49 to $>750,000 \mathrm{cp} / \mathrm{ml}$, plus 23 specimens with PVL under the limit of detection/quantitation. 
The Abbott protocol requires 2 whole spots [27-34], but our previous validations of Roche DNA and Aptima used only two $6 \mathrm{~mm}$ punches (approximately $35 \mathrm{ul}$ of blood or $17 \mathrm{ul}$ of plasma) since DBS samples are sometimes inadequate to allow testing of 2 entire spots. We used two $6 \mathrm{~mm}$ punches for each assay in this comparison. DBS punches were rocked at ambient temperature and extracted according to in-house protocols for each assay. For the Roche DNA, punches were rehydrated in $1 \mathrm{ml}$ Roche Specimen Wash solution (BLD WS) for $1 \mathrm{hr}$; wash solution was discarded and the punches were extracted as for DNA pellets but with 15 min incubations. For the Aptima, punches were eluted in $0.525 \mathrm{ml}$ elution buffer [25] for $2 \mathrm{hr}$ and $0.5 \mathrm{ml}$ of eluate was used for extraction. For the Abbott Qual, punches were eluted in $1.3 \mathrm{ml}$ RNA lysis buffer (Promega, Madison WI) for $2 \mathrm{hr}$; $1.2 \mathrm{ml}$ of eluate was loaded onto the m2000sp for total nucleic acid extraction. McNemar's test was used for statistical comparison of pairwise assay results from the same DBS.

\section{Results}

Specificity estimated among 50 HIV-negative infants was high for all 3 assays (98-100\%, Table 1); the one false-positive Abbott result was negative when re-run on the Abbott assay. Sensitivity estimates varied significantly by assay (Table $1, \mathrm{p}<0.001$ for all assay comparisons). Five of 274 samples were excluded because valid results were not obtained from Roche DNA or Aptima (Roche: 2 indeterminate results, Aptima: 3 not tested due to insufficient specimen). Data from all three assays are plotted in Figure 1. Roche DNA was the most sensitive (96.7\%), followed by Aptima (87.0\%), with Abbott being the least sensitive (66.9\%), with similar sensitivities when restricted to the 151 samples tested on all three assays. Sensitivity increased with PVL; for PVL $<400 \mathrm{cp} / \mathrm{ml}$ (including not detected by the PVL assay), sensitivity ranged from $92.8 \%$ (Roche) to $41.7 \%$ (Abbott); sensitivity improved to $98.8 \%$ (Roche), $96.5 \%$ (Aptima), and 89.9\% (Abbott) among samples with PVL $>400 \mathrm{cp} / \mathrm{ml}$. The Abbott assay only reached $95 \%$ sensitivity when PVL was above $1000 \mathrm{cp} / \mathrm{ml}$.

\section{Discussion}

WHO recommends that HIV-1 virological assays used for early infant diagnosis have sensitivity $\geq 95 \%$ and specificity $\geq 98 \%$ [26]. All three assays achieved the targeted specificity (98-100\%), but only the Roche DNA assay was sufficiently sensitive over the observed range of PVL. The Aptima assay was next best with sensitivities of $87 \%$ overall, and $96.5 \%$ among samples with PVL $>400 \mathrm{cp} / \mathrm{ml}$. The Abbott assay only reached the WHO recommended sensitivity with PVL $>1000 \mathrm{cp} / \mathrm{ml}$ samples.

The lower sensitivity of the Abbott assay was surprising since it is designed to measure total nucleic acid, and the other assays were designed to measure either DNA (Roche DNA) or RNA (Aptima); Aptima may have increased signal due to cellular HIV RNA in infected blood cells, but it was still not as sensitive as the Roche DNA. The automated Abbott extraction requires "dead volume" that is not extracted by the robot, which could affect sensitivity. The Promega Lysis Buffer may not be optimal for total nucleic acid extraction, although it worked well for RNA extraction of DBS on the same platform [35]. There are several published studies using Abbott Lysis buffer for DBS elution prior to extraction for 
the Abbott viral load assay [27-30,32,33], although these studies were of RNA extraction and may not be useful comparisons to Abbott total nucleic acid extraction. While we only used two $6 \mathrm{~mm}$ punches rather than the recommended 2 whole spots, it is clear that the Abbott assay is not as sensitive as the other two assays tested here with equal sample volume. More recent proficiency testing data indicate that using a whole spot increases sensitivity of the Roche and Aptima assays (data not shown).

The Abbott assay was highly sensitive when samples with PVL $>1000 \mathrm{cp} / \mathrm{ml}$ were evaluated, which was more sensitive than in the original evaluation of this assay with DBS [31]. However, infected infants may have very low viral loads (as low as $280 \mathrm{cp} / \mathrm{ml}$ in one study [36]), especially in the few weeks after birth and if they or their mothers have been treated with antiretrovirals [36-40]. Therefore, we do not recommend the Abbott Qualitative HIV-1 assay using DBS for use with infants receiving antiretrovirals as prophylaxis.

Among DBS with PVL $>400 \mathrm{cp} / \mathrm{ml}$, the Gen-Probe Aptima performed well $(96.5 \%$ sensitivity) in this study. Our previous results with the Aptima assay indicated sensitivity in DBS from 39 infected adults down to $20-200 \mathrm{cp} / \mathrm{ml}$ [25]. In that same study we tested DBS from 129 infected infants from several different countries and 162 exposed, uninfected infants and found $99.2 \%$ sensitivity and $100 \%$ specificity [25] despite the fact that some of the DBS had been stored under less than ideal conditions. Differences between infant and adult DBS may account for the different sensitivities of our two studies. Taking into consideration data from this work and our previous study, we have decided to replace the Roche DNA assay with the Gen-Probe Aptima assay using an entire spot.

\section{Acknowledgments}

Technical assistance was provided by Takesha McMillion, Daniel Wilkinson, and Paul Alabanza.

Funding

Funding was provided by the IMPAACT Network (U01-AI068632) through the UNC IMPAACT Specialty Laboratory and the UNC CFAR (P30-AI50410).

\section{References}

[1]. Stevens W, Sherman G, Downing R, Parsons LM, Ou C-Y, Crowley S, et al. Role of the laboratory in ensuring global access to ARV treatment for HIV-infected children: consensus statement on the performance of laboratory assays for early infant diagnosis. Open AIDS J. 2008; 2:17-25. [PubMed: 18923696]

[2]. Patton JC, Sherman GG, Coovadia AH, Stevens WS, Meyers TM. Ultrasensitive human immunodeficiency virus type 1 p24 antigen assay modified for use on dried whole-blood spots as a reliable, affordable test for infant diagnosis. Clin Vaccine Immunol Cvi. 2006; 13:152-5.

[3]. Cassol S, Gill MJ, Pilon R, Cormier M, Voigt RF, Willoughby B, et al. Quantification of human immunodeficiency virus type 1 RNA from dried plasma spots collected on filter paper. J Clin Microbiol. 1997; 35:2795-801. [PubMed: 9350736]

[4]. Fiscus SA, Brambilla D, Grosso L, Schock J, Cronin M. Quantitation of human immunodeficiency virus type 1 RNA in plasma by using blood dried on filter paper. J Clin Microbiol. 1998; 32:25860. [PubMed: 9431960]

[5]. O'Shea S, Mullen J, Corbett K, Chrystie I, Newell ML, Banatvala JE. Use of dried whole blood spots for quantification of HIV-1 RNA. AIDS. 1999; 32:630-1. [PubMed: 10203395]

J Clin Virol. Author manuscript; available in PMC 2015 August 01. 
[6]. Biggar RJ, Broadhead R, Janes M, Kumwenda N, Taha TE, Cassol S. Viral levels in newborn African infants undergoing primary HIV-1 infection. AIDS. 2001; 32:1311-3. [PubMed: 11426078]

[7]. Brambilla D, Jennings C, Aldrovandi G, Bremer J, Comeau AM, Cassol SA, et al. Multicenter evaluation of use of dried blood and plasma spot specimens in quantitative assays for human immunodeficiency virus RNA: measurement, precision, and RNA stability. J Clin Microbiol. 2003; 32:1888-93. [PubMed: 12734222]

[8]. Mwaba P, Cassol S, Nunn A, Pilon R, Chintu C, Janes M, et al. Whole blood versus plasma spots for measurement of HIV-1 viral load in HIV-infected African patients. Lancet. 2003; 32:2067-8. [PubMed: 14697808]

[9]. Uttayamakul S, Likanonsakul S, Sunthornkachit R, Kuntiranont K, Louisirirotchanakul S, Chaovavanich A, et al. Usage of dried blood spots for molecular diagnosis and monitoring HIV-1 infection. J Virol Methods. 2005; 32:128-34. [PubMed: 15913797]

[10]. Rollins NC, Dedicoat M, Danaviah S, Page T, Bishop K, Kleinschmidt I, et al. Prevalence, incidence, and mother-to-child transmission of HIV-1 in rural South Africa. Lancet. 2002; 360:389. [PubMed: 12241784]

[11]. Cassol S, Salas T, Arella M, Neumann P, Schechter MT, O’Shaughnessy M. Use of dried blood spot specimens in the detection of human immunodeficiency virus type 1 by the polymerase chain reaction. J Clin Microbiol. 1991; 32:667-71. [PubMed: 1890166]

[12]. Cassol SA, Lapointe N, Salas T, Hankins C, Arella M, Fauvel M, et al. Diagnosis of vertical HIV-1 transmission using the polymerase chain reaction and dried blood spot specimens. $\mathrm{J}$ Acquir Immune Defic Syndr. 1992; 32:113-9. [PubMed: 1732502]

[13]. Comeau AM, Harris JA, McIntosh K, Weiblen BJ, Hoff R, Grady GF. Polymerase chain reaction in detecting HIV infection among seropositive infants: relation to clinical status and age and to results of other assays. J Acquir Immune Defic Syndr. 1992; 32:271-8. [PubMed: 1740753]

[14]. Cassol S, Butcher A, Kinard S, Spadoro J, Sy T, Lapointe N, et al. Rapid screening for early detection of mother-to-child transmission of human immunodeficiency virus type 1 . J Clin Microbiol. 1994; 32:2641-5. [PubMed: 7852549]

[15]. Yourno J, Conroy J. A novel polymerase chain reaction method for detection of human immunodeficiency virus in dried blood spots on filter paper. J Clin Microbiol. 1992; 32:2887-92. [PubMed: 1452659]

[16]. Comeau AM, Hsu HW, Schwerzler M, Mushinsky G, Walter E, Hofman L, et al. Identifying human immunodeficiency virus infection at birth: application of polymerase chain reaction to Guthrie cards. J Pediatr. 1993; 32:252-8. [PubMed: 8345421]

[17]. Nyambi PN, Fransen K, De Beenhouwer H, Chomba EN, Temmerman M, Ndinya-Achola JO, et al. Detection of human immunodeficiency virus type 1 (HIV-1) in heel prick blood on filter paper from children born to HIV-1-seropositive mothers. J Clin Microbiol. 1994; 32:2858-60. [PubMed: 7852588]

[18]. Biggar RJ, Miley W, Miotti P, Taha TE, Butcher A, Spadoro J, et al. Blood collection on filter paper: a practical approach to sample collection for studies of perinatal HIV transmission. $\mathrm{J}$ Acquir Immune Defic Syndr Hum Retrovirology. 1997; 32:368-73. [PubMed: 9111480]

[19]. Panteleeff DD, John G, Nduati R, Mbori-Ngacha D, Richardson B, Kreiss J, et al. Rapid method for screening dried blood samples on filter paper for human immunodeficiency virus type 1 DNA. J Clin Microbiol. 1999; 32:350-3. [PubMed: 9889216]

[20]. Beck IA, Drennan KD, Melvin AJ, Mohan KM, Herz AM, Alarcón J, et al. Simple, sensitive, and specific detection of human immunodeficiency virus type 1 subtype B DNA in dried blood samples for diagnosis in infants in the field. J Clin Microbiol. 2001; 32:29-33. [PubMed: 11136743]

[21]. Fischer A, Lejczak C, Lambert C, Servais J, Makombe N, Rusine J, et al. Simple DNA extraction method for dried blood spots and comparison of two PCR assays for diagnosis of vertical human immunodeficiency virus type 1 transmission in Rwanda. J Clin Microbiol. 2004; 32:16-20. [PubMed: 14715726] 
[22]. Sherman GG, Stevens G, Jones SA, Horsfield P, Stevens WS. Dried blood spots improve access to HIV diagnosis and care for infants in low-resource settings. J Acquir Immune Defic Syndr. 2005; 32:615-7. [PubMed: 15793374]

[23]. Sriwanthana B, Wetprasit N, Chareonsook S, Janejai N, Chareonsiriwatana W. A study to implement early diagnosis of HIV infection in infants born to infected mothers. Southeast Asian J Trop Med Public Health. 2003; 34(Suppl 3):221-6. [PubMed: 15906740]

[24]. Li C-C, Beck IA, Seidel KD, Frenkel LM. Persistence of human immunodeficiency virus type 1 subtype B DNA in dried-blood samples on FTA filter paper. J Clin Microbiol. 2004; 32:3847-9. [PubMed: 15297546]

[25]. Kerr RJS, Player G, Fiscus SA, Nelson JAE. Qualitative human immunodeficiency virus RNA analysis of dried blood spots for diagnosis of infections in infants. J Clin Microbiol. 2009; 32:220-2. [PubMed: 19005148]

[26]. HIV/AIDS Programme: WHO Recommendations on the Diagnosis of HIV Infection in Infants and Children. 2010.

[27]. Garrido C, Zahonero N, Corral A, Arredondo M, Soriano V, de Mendoza C. Correlation between human immunodeficiency virus type 1 (HIV-1) RNA measurements obtained with dried blood spots and those obtained with plasma by use of Nuclisens EasyQ HIV-1 and Abbott RealTime HIV load tests. J Clin Microbiol. 2009; 32:1031-6. [PubMed: 19193847]

[28]. Marconi A, Balestrieri M, Comastri G, Pulvirenti FR, Gennari W, Tagliazucchi S, et al. Evaluation of the Abbott Real-Time HIV-1 quantitative assay with dried blood spot specimens. Clin Microbiol Infect. 2009; 32:93-7. [PubMed: 19220340]

[29]. Mbida AD, Sosso S, Flori P, Saoudin H, Lawrence P, Monny-Lobé M, et al. Measure of viral load by using the Abbott Real-Time HIV-1 assay on dried blood and plasma spot specimens collected in 2 rural dispensaries in Cameroon. J Acquir Immune Defic Syndr. 2009; 32:9-16. [PubMed: 19620878]

[30]. Lofgren SM, Morrissey AB, Chevallier CC, Malabeja AI, Edmonds S, Amos B, et al. Evaluation of a dried blood spot HIV-1 RNA program for early infant diagnosis and viral load monitoring at rural and remote healthcare facilities. AIDS. 2009; 32:2459-66. [PubMed: 19741481]

[31]. Huang S, Erickson B, Mak WB, Salituro J, Abravaya K. A novel RealTime HIV-1 Qualitative assay for the detection of HIV-1 nucleic acids in dried blood spots and plasma. J Virol Methods. 2011; 32:216-24. [PubMed: 21968095]

[32]. Arredondo M, Garrido C, Parkin N, Zahonero N, Bertagnolio S, Soriano V, et al. Comparison of HIV-1 RNA measurements obtained by using plasma and dried blood spots in the automated abbott real-time viral load assay. J Clin Microbiol. 2012; 32:569-72. [PubMed: 22170904]

[33]. Vidya M, Saravanan S, Rifkin S, Solomon SS, Waldrop G, Mayer KH, et al. Dried blood spots versus plasma for the quantitation of HIV-1 RNA using a real-Time PCR, m2000rt assay. J Virol Methods. 2012; 32:177-81. [PubMed: 22401801]

[34]. Monleau M, Montavon C, Laurent C, Segondy M, Montes B, Delaporte E, et al. Evaluation of different RNA extraction methods and storage conditions of dried plasma or blood spots for human immunodeficiency virus type 1 RNA quantification and PCR amplification for drug resistance testing. J Clin Microbiol. 2009; 32:1107-18. [PubMed: 19193835]

[35]. Loftis, A.; Kshatriya, R.; McCall-Culbreath, K.; Webster-Cyriaque, J.; Fiscus, S.; Nelson, J. Optimization of Abbott m2000 RealTime HIV-1 Viral Load Assay on Breastmilk, Dried Blood Spots, Genital Secretions, Cerebrospinal Fluid, Urine, and Throatwash; APHL HIV Diagnostics Conference; Orlando FL. 2010;

[36]. Lee BE, Plitt SS, Jayaraman GC, Chui L, Singh AE, Preiksaitis JK. Use of Quantitative HIV RNA Detection for Early Diagnosis of HIV Infection in Infants and Acute HIV Infections in Alberta, Canada. J Clin Microbiol. 2011; 32:502-5. [PubMed: 22162550]

[37]. Nesheim S, Palumbo P, Sullivan K, Lee F, Vink P, Abrams E, et al. Quantitative RNA Testing for Diagnosis of HIV-Infected Infants. J Acquir Immune Defic Syndr. 2003; 32:192-5. [PubMed: 12571529]

[38]. Burgard M, Blanche S, Jasseron C, Descamps P, Allemon M-C, Ciraru-Vigneron N, et al. Performance of HIV-1 DNA or HIV-1 RNA tests for early diagnosis of perinatal HIV-1 infection during anti-retroviral prophylaxis. J Pediatr. 2012; 32:60-66. [PubMed: 21868029] 
[39]. Lilian RR, Kalk E, Bhowan K, Berrie L, Carmona S, Technau K, et al. Early diagnosis of in utero and intrapartum HIV infection in infants prior to 6 weeks of age. J Clin Microbiol. 2012; 32:2373-7. [PubMed: 22518871]

[40]. Connolly MD, Rutstein RM, Lowenthal ED. Virologic testing in infants with perinatal exposure to HIV receiving multidrug prophylaxis. Pediatr Infect Dis J. 2013; 32:196-7. [PubMed: 23328830] 


\section{Highlights}

The gold standard infant diagnosis assay for HIV is being discontinued.

An alternative assay for early infant diagnosis of HIV is needed.

Dried blood spots (DBS) are an important specimen type for infant diagnosis of HIV.

We compared three nucleic acid-based HIV diagnosis assays using DBS.

One of the two new assays is a good alternate for the gold standard assay with DBS. 


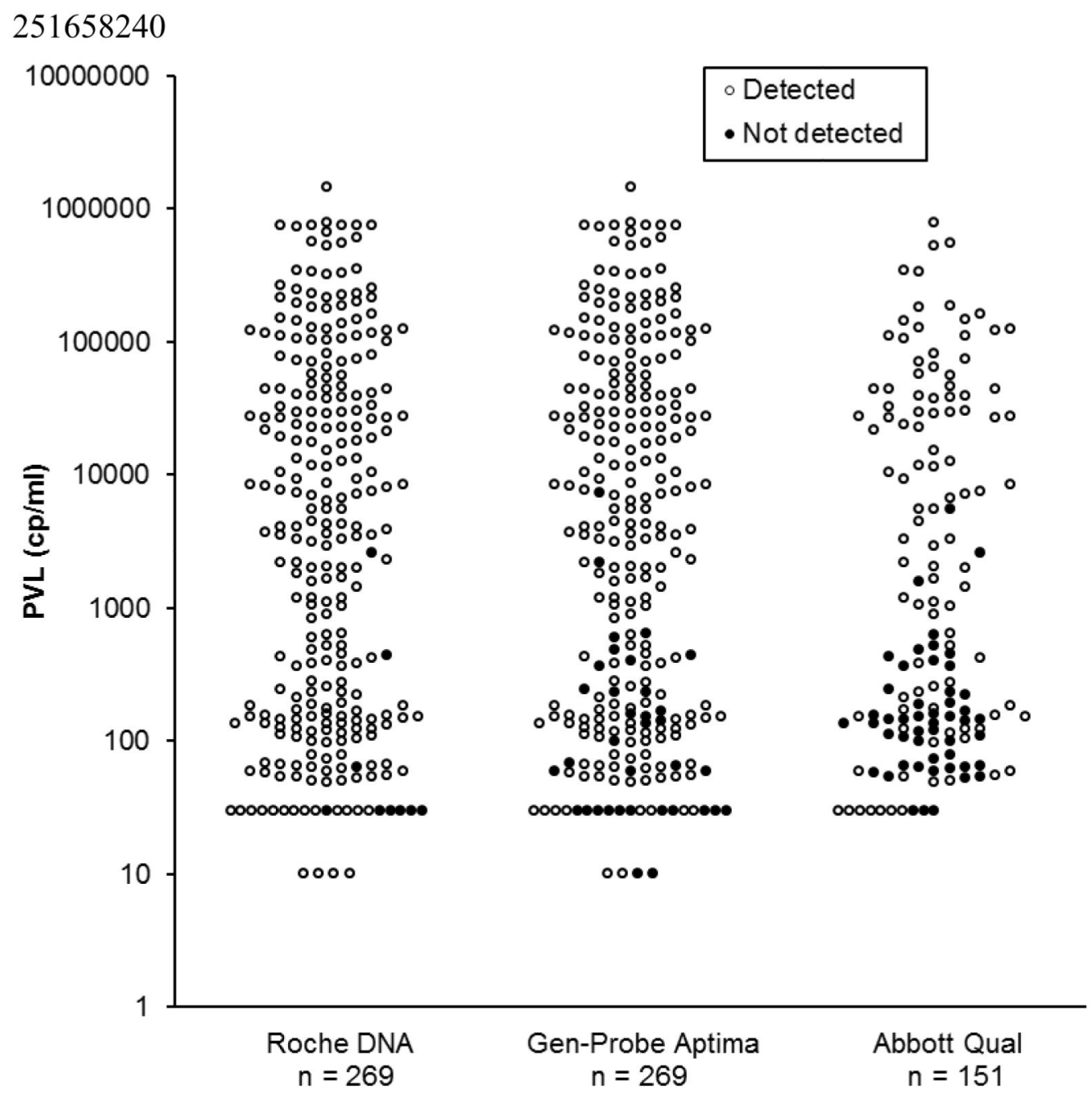

Figure 1.

Results from each assay with DBS from HIV-positive adults, plotted against PVL. Each specimen is plotted in the same relative position for the three assays. Missing dots were not tested on the Abbott assay. Results plotted at $30 \mathrm{cp} / \mathrm{ml}$ had PVL of $<400 \mathrm{cp} / \mathrm{mL}$ on the Roche Amplicor HIV-1 Monitor version 1.5, standard protocol; results plotted at $10 \mathrm{cp} / \mathrm{ml}$ had PVL $<40 \mathrm{cp} / \mathrm{ml}$ (detected or not) on the Abbott RealTime HIV-1 assay. 


\section{Table 1}

Characteristics of three assays using DBS.

\begin{tabular}{|c|c|c|c|}
\hline \multicolumn{2}{|c|}{ Specificity among DBS from HIV-exposed uninfected infants } \\
\hline & \multicolumn{3}{|c|}{$\begin{array}{c}\text { Results } \\
\text { (Estimate) } \\
\text { [95\% confidence interval }]^{\boldsymbol{a}}\end{array}$} \\
\hline & Roche DNA & $\begin{array}{c}\text { Gen-Probe } \\
\text { Aptima }\end{array}$ & Abbott Qual \\
\hline Specificity & $\begin{array}{c}50 / 50 \\
(100 \%) \\
{[92.9-100]}\end{array}$ & $\begin{array}{c}50 / 50 \\
(100 \%) \\
{[92.9-100]}\end{array}$ & $\begin{array}{c}49 / 50 \\
(98.0 \%) \\
{[89.4-99.9]}\end{array}$ \\
\hline
\end{tabular}

\begin{tabular}{|c|c|c|c|}
\hline \multicolumn{4}{|c|}{ Sensitivity among DBS from HIV-infected adults } \\
\hline All results & $\begin{array}{c}260 / 269 \\
(96.7 \%) \\
{[93.7-98.5]}\end{array}$ & $\begin{array}{c}234 / 269 \\
(87.0 \%) \\
{[82.4-90.8]}\end{array}$ & $\begin{array}{c}101 / 151 \\
(66.9 \%) \\
{[58.8-74.3]}\end{array}$ \\
\hline $\begin{array}{l}\text { Subset with results } \\
\text { from all } 3 \text { assays } b\end{array}$ & $\begin{array}{c}148 / 151 \\
(98.0 \%) \\
{[94.3-99.6]}\end{array}$ & $\begin{array}{c}128 / 151 \\
(84.8 \%) \\
{[78.0-90.1]}\end{array}$ & $\begin{array}{c}101 / 151 \\
(66.9 \%) \\
{[58.8-74.3]}\end{array}$ \\
\hline $\begin{array}{l}\text { Subset with PVL }<400 \mathrm{cp} / \mathrm{ml} \\
\text { or not detected }\end{array}$ & $\begin{array}{c}90 / 97 \\
(92.8 \%) \\
{[85.7-97.0]}\end{array}$ & $\begin{array}{c}68 / 97 \\
(70.1 \%) \\
{[60.0-79.0]}\end{array}$ & $\begin{array}{c}30 / 72 \\
(41.7 \%) \\
{[30.2-53.9]}\end{array}$ \\
\hline Subset with PVL $>400 \mathrm{cp} / \mathrm{ml}$ & $\begin{array}{c}170 / 172 \\
(98.8 \%) \\
{[95.9-99.9]}\end{array}$ & $\begin{array}{c}166 / 172 \\
(96.5 \%) \\
{[92.6-98.7]}\end{array}$ & $\begin{array}{c}71 / 79 \\
(89.9 \%) \\
{[81.0-95.5]}\end{array}$ \\
\hline $\begin{array}{l}\text { Subset with PVL > } 1000 \\
\mathrm{cp} / \mathrm{ml}\end{array}$ & $\begin{array}{c}159 / 160 \\
(99.4 \%) \\
{[96.6-100]}\end{array}$ & $\begin{array}{c}158 / 160 \\
(98.8 \%) \\
{[95.6-99.8]}\end{array}$ & $\begin{array}{c}67 / 70 \\
(95.7 \%) \\
{[88.0-99.1]}\end{array}$ \\
\hline
\end{tabular}

DBS = dried blood spot. $\mathrm{PVL}=$ plasma viral load .

${ }^{a}$ Clopper-Pearson exact $95 \%$ confidence interval.

${ }^{b}$ McNemar's exact test among paired sensitivity results: Roche vs. Aptima ( $\left.<<0.001\right)$, Roche vs. Abbott $(\mathrm{p}<0.001)$, Aptima vs. Abbott $(\mathrm{p}<0.001)$ 